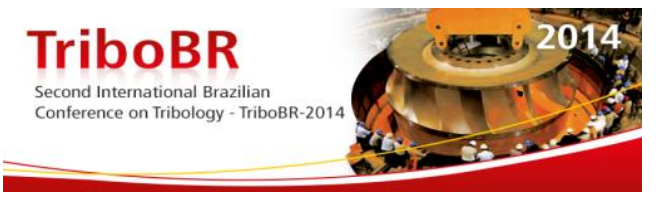

\title{
EFFECT OF TEMPERATURE AND ATMOSPHERE ON THE TRIBOLOGICAL BEHAVIOUR OF HIGH TRIBOLOGICAL PERFORMANCE PEEK (POLYETHER ETHER KETONE) COMPOSITE*
}

\author{
Felipe Darabas Rzatki ${ }^{1}$ \\ Diego Vinicius Dalevedo Barboza ${ }^{2}$ \\ Renan Muller Schroeder ${ }^{3}$ \\ Guilherme Mariz de Oliveira Barra ${ }^{4}$ \\ Cristiano Binder 5 \\ Aloisio Nelmo Klein 6 \\ José Daniel Biasoli de Mello
}

\begin{abstract}
Polyether ether ketone (PEEK) is a high performance thermoplastic often selected for high temperature tribological applications under chemically aggressive environments. The present work evaluate the tribological behavior of a high performance PEEK composite under ambient and high temperature $\left(30\right.$ and $80^{\circ} \mathrm{C}$, respectively). The atmosphere was also varied (air or tetrafluorethane). An AMTI tribometer equipped with a hermetic chamber and a heating system was used to carry out sliding tests of PEEK cylinders on 304 stainless steel polished discs $(\mathrm{Sq}<10 \mathrm{~nm})$ with reciprocating movement and $175 \mathrm{~N}$ normal force. Surfaces roughness analyses were performed with a white light interferometer. As expected, there was a strong influence of temperature on the tribological behavior of the samples tested in ambient atmosphere $(25 \%$ decrease in friction coefficient associated with a $100 \%$ increase in wear rate). On the other hand, samples tested in tetrafluorethane atmosphere showed no significant friction temperature dependence.
\end{abstract}

Keywords: Solid lubricant; Thermoplastics; Environment; Temperature.

\footnotetext{
MSc, researcher, materials laboratory, UFSC, Florianópolis, SC, Brazil.

Undergraduate, materials laboratory, UFSC, Florianópolis, SC, Brazil.

MSc, project manager, R\&D solutions, Whirlpool/Embraco, Joinville, SC, Brazil.

Dr. Eng., professor, mechanical engineering dep., UFSC, Florianópolis, SC, Brazil.

Dr. Eng., researcher, materials laboratory, UFSC, Florianópolis, SC, Brazil.

Doc. Ing., professor, mechanical engineering department, UFSC, Florianópolis, SC, Brazil.

Doc. Ing., visiting professor, mechanical engineering department, UFSC, Florianópolis, SC, Brazil.
}

\footnotetext{
* Technical contribution to the $2^{\text {nd }}$ International Brazilian Conference on Tribology - TriboBR 2014, November $3^{\text {rd }}$ to $5^{\text {th }}$, 2014, Foz do Iguaçu, PR, Brazil.
} 


\section{INTRODUCTION}

Through the last decades, refrigerant industry has changed the used refrigerant fluid several times, generally driven by environmental issues [1-7]. More recently, refrigerant industry has shown interest in oil-less compressors $[8,9]$. This new generation of products, besides environmental benefits, reaches new levels of efficiency and allow the development of innovative refrigerators [10]. In this context, solid lubricant polymeric materials are a promising alternative to keep low friction and wear in lubricant-free systems. However, the harsh operation condition of compressors requires the use of high performance polymers, and compounds based on Polyether-ether-ketone (PEEK) are certainly some of the most promissory materials in current polymer tribology [11].

Few investigations of tribological behavior of polymeric materials in refrigerant atmospheres and dry conditions are available [2-7]. Cannaday \& Polycarpou [3] found that tetrafluorethane refrigeration atmosphere resulted in tribological properties slightly superior than atmospheric air for several polymeric materials and composites. Moreover, MacCooK et al. [12] presented that neat PEEK showed lower friction coefficient and wear in dry and vacuum environments. However, the temperature effect on sliding wear of polymeric composites under refrigerant atmosphere is still unclear.

The main goal of the present work is to investigate the impact of high temperatures and refrigerant atmospheres on the tribological behavior of a wear resistance solid lubricated PEEK composite. On top of that, harsh cylinder-on-disc configuration and oscillatory movement were chosen as test conditions. White light interferometer, optical image analyses and Raman spectroscopy provide further insights about possible interactions between polymer composites and test environment.

\section{MATERIAL AND METHODS}

A commercially available 10\% PTFE, 10\% Graphite and 10\% Carbon Fiber (CF) filled PEEK composite was selected due to its superior self-lubricating and wear characteristics [11]. Table 1 presents nominal mechanical properties of this PEEK composite. The material was provided as an $11 \mathrm{~mm}$ thick injection molded plate which was machined to $8 \mathrm{~mm}$ rods and then sliced into $4 \mathrm{~mm}$ height cylinders.

Table 1. Mechanical and tribological properties of PTFE+Graphite+CF filled PEEK

\begin{tabular}{ccc}
\hline $\begin{array}{c}\text { Modulus } \\
(\mathrm{GPa})\end{array}$ & $\begin{array}{c}\text { Hardness } \\
\text { (Rockwell M) }\end{array}$ & $\begin{array}{c}\text { Tensile strength } \\
\text { (MPa) }\end{array}$ \\
\hline 11 & 80 & 150 \\
\hline
\end{tabular}

These PEEK cylinders were analyzed in dry tribological tests under atmospheric air or tetrafluorethane atmosphere at low and high temperatures $\left(30\right.$ and $80^{\circ} \mathrm{C}$, respectively) in a custom-made AMTI tribometer. This apparatus is equipped with a hermetic chamber, a heating system and a two-channel load cell. Tribological tests were carried out with oscillatory linear movements in a cylinder-on-plate configuration (Figure 1), where the counter body is an AISI 304 stainless steel polished disc, with surface roughness (root mean square $-\mathrm{S}_{\mathrm{q}}$ ) lower than $10 \mathrm{~nm}$. The tests had duration of 2 hours under $175 \mathrm{~N}$ normal load with frequency of $2 \mathrm{~Hz}$ and $10 \mathrm{~mm}$ stroke. Tests characteristics and parameters were chosen in order to closely reproduce operation conditions acting in hermetic compressors. Polymer wear rates were calculated using

\footnotetext{
* Technical contribution to the $2^{\text {nd }}$ International Brazilian Conference on Tribology - TriboBR 2014, November $3^{\text {rd }}$ to $5^{\text {th }}$, 2014, Foz do Iguaçu, PR, Brazil.
} 


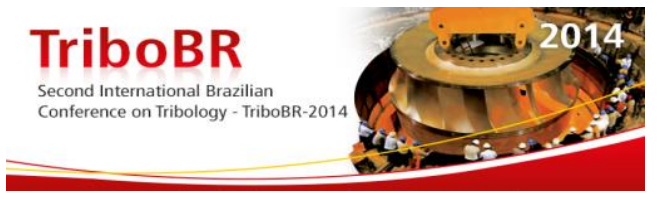

wear volume measurements obtained by using a white-light interferometer (Zygo New View 7200). The results are the average of, at least, 3 tests for each condition.

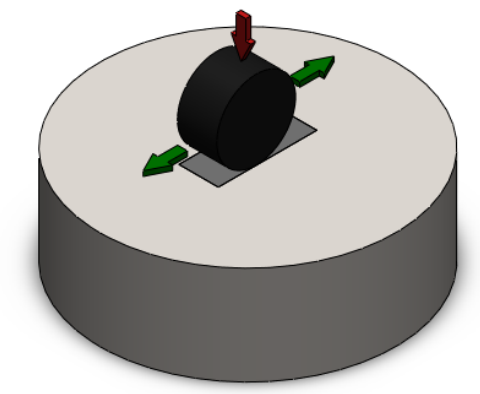

Figure 1. Cylinder-on-plate configuration. Red arrow indicates normal force. Green arrows indicate the sliding movement of PEEK cylinders.

Wear tracks were analyzed by white-light interferometry, optical image analyses and Raman spectroscopy (Renishaw 2000, equipped with $514 \mathrm{~nm}$ argon laser) in order to access further information about wear mechanisms and tribolayer formation. A Gaussian filter $(800 \mu \mathrm{m})$ where applied to surface roughness analysis in order remove waviness from samples surface.

\section{RESULTS AND DISCUSSION}

The wear that PEEK samples experienced through sliding tests followed the same trend in all tests conditions. The initial linear contact, with maximum Hertzian pressure of $290 \mathrm{MPa}$, evolved to large contact areas, with nominal pressure of around $40 \mathrm{MPa}$ (Figure 2). Geometric data showed that the fiber-reinforced composites did not undergo long-range plastic deformation. Therefore, the enlargement of apparent contact area is assign, exclusively, to material removal, i.e. volumetric wear.
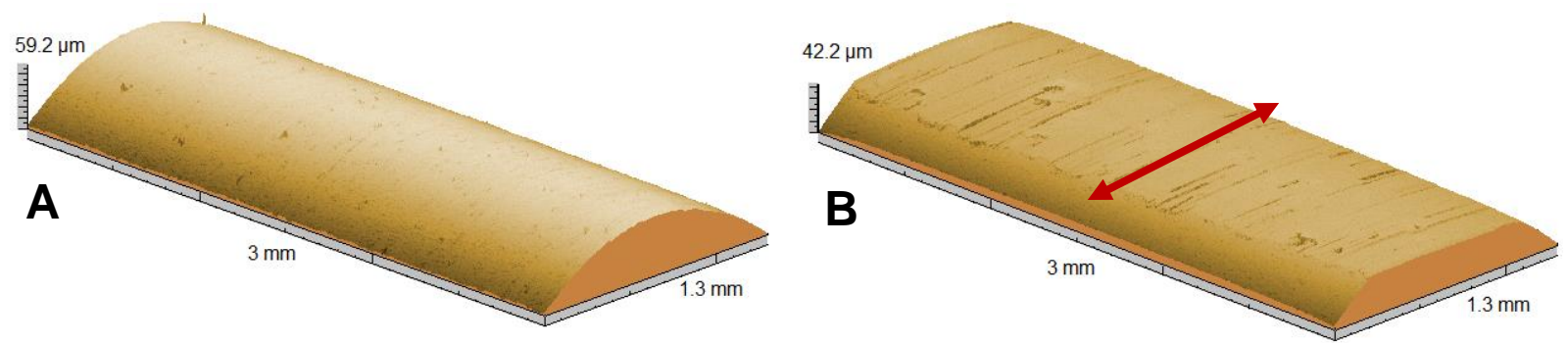

Figure 2. Geometry of PEEK cylinder before (A) and after (B) wear test at $30^{\circ} \mathrm{C}$ and tetrafluorethane atmosphere. Red arrow indicates sliding direction

The wear rates resulting from these volumetric losses are show in Figure 3. Unlike coefficient of friction, wear rates showed no significant ambient atmosphere dependence. Cannaday \& Polycarpou [3] reported that PEEK and PEEK composites showed a slight wear rate reduction when tested in tetrafluorethane atmosphere. On the other hand, temperature drove wear rates from $1.7 \times 10^{-6} \mathrm{~mm}^{3} / \mathrm{N} . \mathrm{m}$, at $30^{\circ} \mathrm{C}$, to approximately $3.5 \times 10^{-6} \mathrm{~mm}^{3} / \mathrm{N} \cdot \mathrm{m}$, at $80^{\circ} \mathrm{C}$. The latter behavior is attributed to polymer thermal softening [13-15].

* Technical contribution to the $2^{\text {nd }}$ International Brazilian Conference on Tribology - TriboBR 2014, November $3^{\text {rd }}$ to $5^{\text {th }}$, 2014, Foz do Iguaçu, PR, Brazil. 


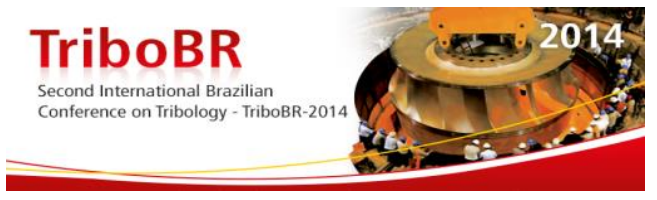

occur and it is possible to attribute the grooves formation to abrasive mechanisms of microploughing [16]. Since successive ploughing leads to microfatigue wear mechanisms [16], one can consider these grooves were produced, mainly, in the earlier stages of tribological contact.

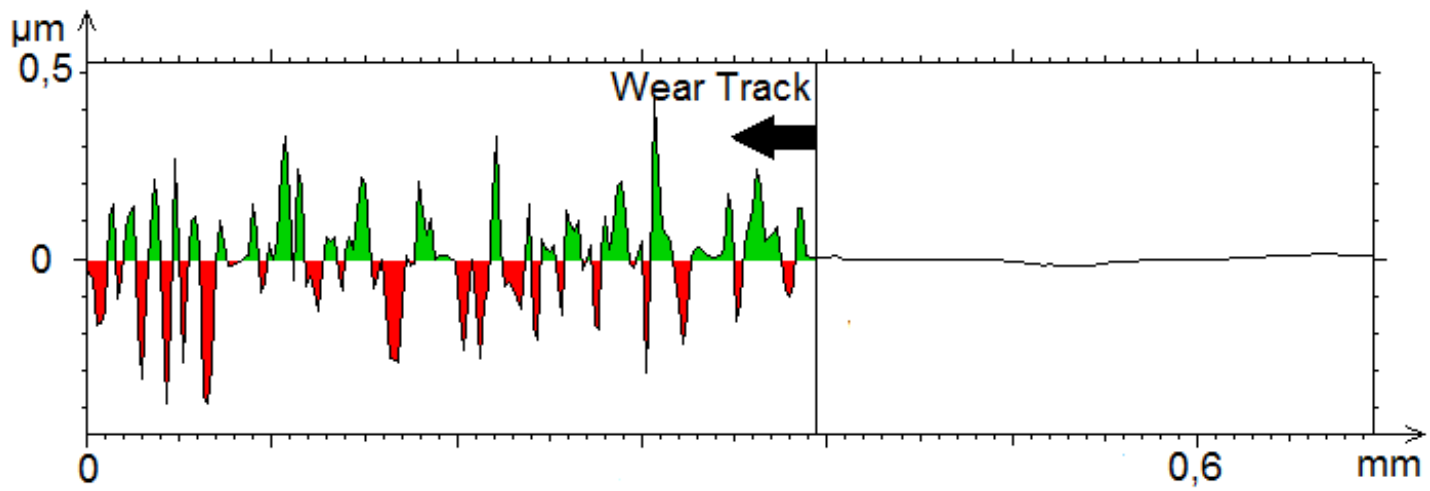

Figure 6. Topography profile (transverse to sliding direction) extracted from wear track boundary of counter body tested under atmospheric air at $80^{\circ} \mathrm{C}$. Green and red areas show wear track peaks and valleys, respectively, in relation to the mean height from the virgin region.

Figure 7 presents typical results from image analyses of worn samples. Micrographs from PEEK wear regions revealed grooves aligned in the direction of sliding, typical from microploughing wear mechanisms, and shear induced plastic flow regions in the boundary of worn surfaces, attributed to smearing $[11,14,16]$. Additionally, as cylinders wear out, one can observe carbon fibers being exposed to tribological contact. These hard spots are able to plough counter bodies surface, forming the grooves showed in Figure $4[17,18]$. In return, the abraded metallic surfaces, filled with sharp asperities, are able to plough polymers surface and wear out carbon fibers edges. On the other hand, although topography analyses did not evidenced significant material deposition on wear tracks, micrographs from counter bodies surfaces revealed the formation of a tribo-layer. It worth noting that free carbon fibers were not observed on counter body surface
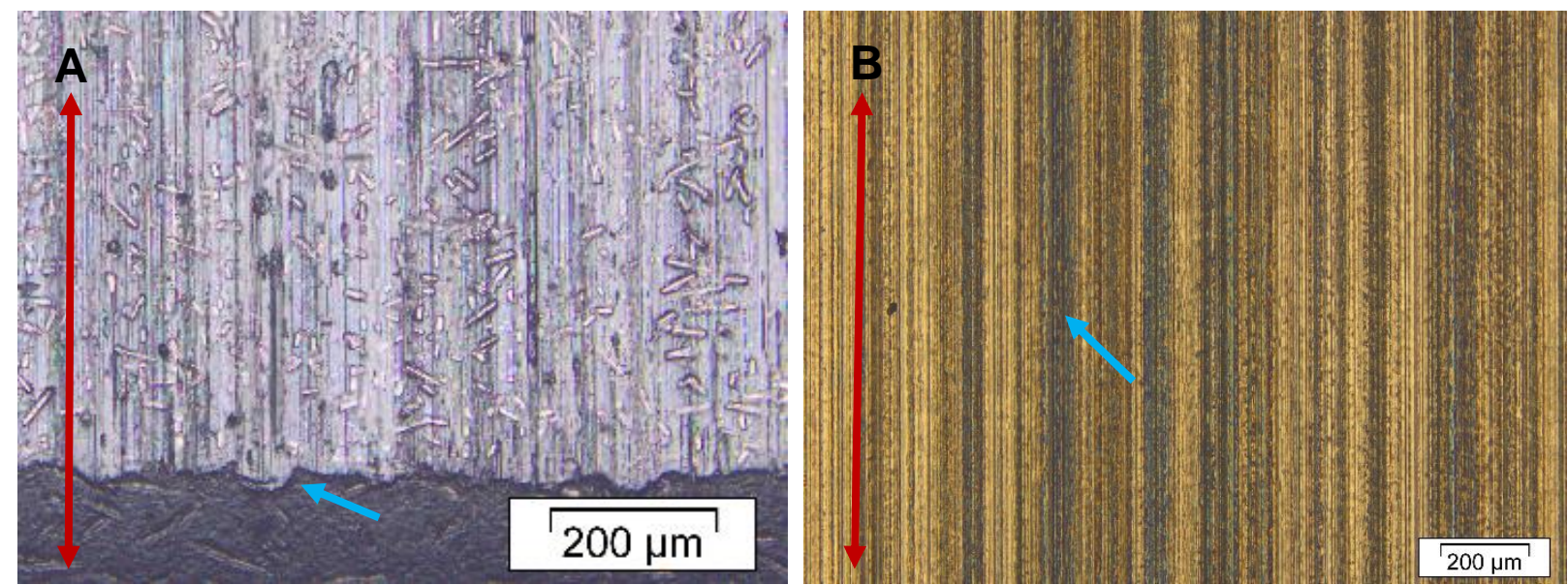

Figure 7. Optical micrographs of polymer $(A)$ and counter body $(B)$ worn regions from samples tested under atmospheric air at $80^{\circ} \mathrm{C}$. Red arrows indicate sliding direction. Blue arrows indicate regions of shear induced plastic flow (left) and material deposition (right)

Raman spectroscopy analyses (Figure 8) from counter bodies wear tracks showed D $\left(\sim 1360 \mathrm{~cm}^{-1}\right)$ and $\mathrm{G}\left(\sim 1580 \mathrm{~cm}^{-1}\right)$ bands, which are common to graphite-based structures $[19,20]$. The low bands intensity obtained from samples tested at $30^{\circ} \mathrm{C}$

\footnotetext{
* Technical contribution to the $2^{\text {nd }}$ International Brazilian Conference on Tribology - TriboBR 2014, November $3^{\text {rd }}$ to $5^{\text {th }}$, 2014, Foz do Iguaçu, PR, Brazil.
} 


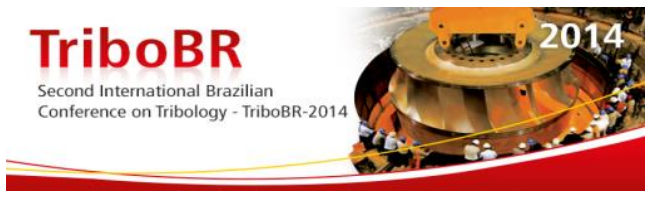

indicates that the tribo-layer formed in these test conditions is too thin. This behavior is in agreement to Sheiretov et al. [2], who reported that higher temperatures enhance the formation of uniform tribo-layers. On the other hand, the higher intensity ratio between $D$ and $G$ bands (ID/IG) from samples tested under atmospheric air at $80{ }^{\circ} \mathrm{C}\left(0.97\right.$, against 0.70 from tetrafluorethane at $\left.80^{\circ} \mathrm{C}\right)$ indicates a higher disorder on graphite structure $[19,20]$. However, the origin of these graphite-based layers remains undiscovered, since it can be attributed to different carbon sources such as: i) graphite fillers from polymer composition; ii) degraded polymers (PEEK and PTFE); iii) degraded carbon fibers.

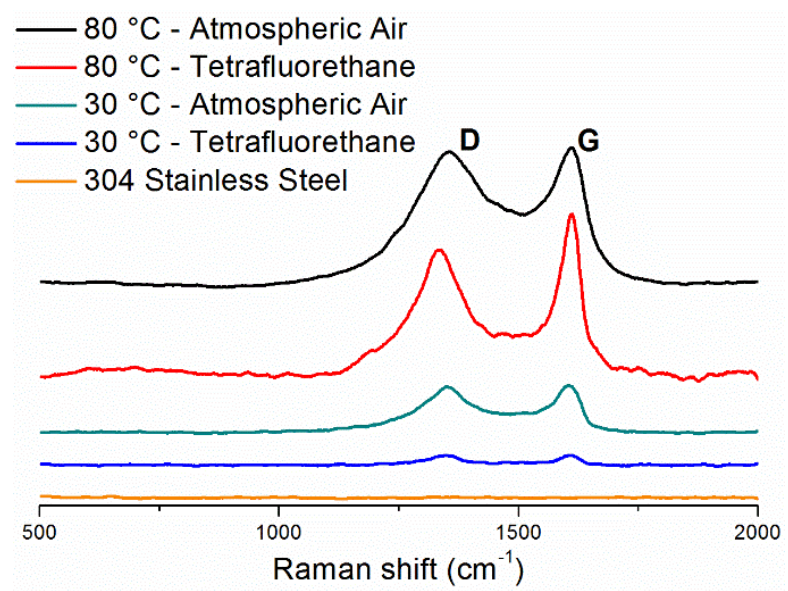

Figure 8. Wear tracks Raman spectrums. Raman spectrum from virgin AISE 304 stainless stell is also displayed

Figure 9 presents typical evolution of the friction coefficient with test time and the average coefficient of friction (COF), calculated in the steady state regime, for each studied condition.
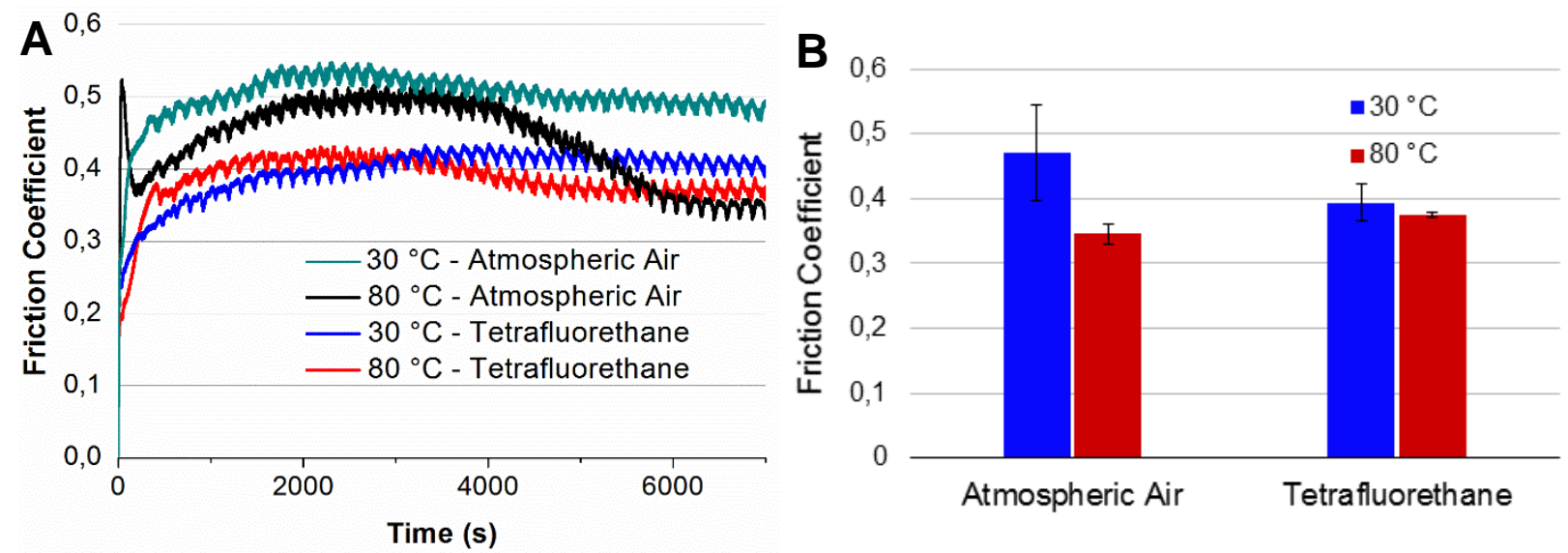

Figure 9. Friction behavior (A) and steady state friction coefficients (B) of PEEK composites sliding against 304 stainless steel discs

Figure $9(\mathrm{~A})$ shows how the evolution of COF during the test duration is influenced by the chamber atmosphere and temperature. All results present similar behavior. Initially, there is a gradual increase followed by a maximum, and them, after a drop, a steady state is reached. At maximum point, samples tested in atmospheric air exhibited COF $40 \%$ higher than samples tested in tetrafluoretane atmosphere. After this point, samples tested at $80{ }^{\circ} \mathrm{C}$ exhibited a friction coefficient drop of $30 \%$, under atmospheric air, and of $14 \%$, under tetrafluorethane atmosphere. Samples tested at

* Technical contribution to the $2^{\text {nd }}$ International Brazilian Conference on Tribology - TriboBR 2014, November $3^{\text {rd }}$ to $5^{\text {th }}$, 2014, Foz do Iguaçu, PR, Brazil. 


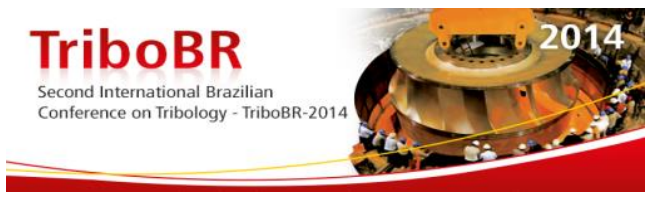

$30^{\circ}$ showed slopes of $9 \%$. Thus, the steady state COF was drastically affected by temperature under atmospheric air, going from 0.47 at $30^{\circ} \mathrm{C}$ to 0.34 at $80^{\circ} \mathrm{C}$. On the other hand, samples tested under tetrafluorethane atmosphere showed no significant temperature dependence, with friction coefficients varying around 0.38 .

Friction behavior observed in Figure 9 was a result from the addition of adhesive interfacial forces, ploughing on polymeric samples and ploughing on counter bodies surfaces. Moreover, the intensity of each of these portions is a function of contact pressure, contact topography and tribo-layer characteristics. Therefore, based on observed wear characteristics, it is possible to delineate the following assumptions regarding to observed friction behavior.

In the beginning, the linear contact pressure, which is higher than polymer tensile strength, readily worn the cylinder surface, exposing sharp carbon fibers to the tribological contact. As the composite cylinder wears out, more fibers are available to plough the counter body surface, leading to a fast increase COF as observed in Figure 9.

Besides, this harsh abrasive environment could prevent the formation of a protective tribo-layer, which would explain the higher transient COF observed at samples tested in atmospheric air in Figure 9 [12]. Without a protective tribo-layer the interfacial adhesive forces would be attributed to interactions between PEEK matrix and metallic surface. Thus, according to McCook et al. [12], the relative humidity around $40 \%$ present in atmospheric air increases the COF of PEEK matrix running against metallic surfaces.

With the increase of contact area, eventually, the contact pressure reduces to values below the polymer tensile strength and microploughing and adhesive mechanisms, observed in Figure 7, prevail. Reducing polymer wear rate, few new fibers got exposed to tribological contact. On top of that, carbon fibers edges wear out. As a result, the gradual increase of COF starts to slow down.

An attenuation of abrasive mechanisms could also enhance the formation of a protective tribo-layer as the graphite based structure observed in Figures 7 and 8, which could drop the COF as observed in Figure 9. Lower temperatures as $30^{\circ} \mathrm{C}$ prevents or slows down the formation of an uniform tribo-layer, which results in a small drop in transient COF [2]. According to Yen et al. [21] "The presence of vapors, such as water, is required for graphite to lubricate". Thus, the water vapor present in atmospheric air reduces the bonding energy between the hexagonal planes of graphite structures which could explain the lower steady state COF observed in samples tested in atmospheric air at $80^{\circ} \mathrm{C}$.

At last, the steady-state COF prevail indicates that contact pressure, contact topography and tribo-layer stabilized.

\section{CONCLUSION}

Table 2 summarizes the observed tribological behavior. PEEK composite wear rates were drastically influenced by test temperature, but no significant atmosphere dependence was detected. AISI 304 counter bodies wear lead to increased surface roughness $\left(R_{q}\right)$ in all testing conditions, but no volumetric losses were detected. Samples tested in atmospheric air showed higher COF through transient regime. However, at steady state regime, samples tested in atmospheric air at $80^{\circ} \mathrm{C}$ showed the lowest COF. On the other hand, samples tested in tetrafluorethane atmosphere showed no significant friction temperature dependence.

\footnotetext{
* Technical contribution to the $2^{\text {nd }}$ International Brazilian Conference on Tribology - TriboBR 2014, November $3^{\text {rd }}$ to $5^{\text {th }}$, 2014, Foz do Iguaçu, PR, Brazil.
} 


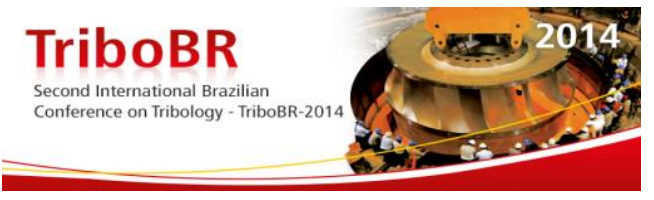

Table 2. Summary of tribological behavior

\begin{tabular}{ccccc}
\hline Test Condition & $\begin{array}{c}\text { Max. transient } \\
\text { COF }\end{array}$ & $\begin{array}{c}\text { Steady state } \\
\text { COF }\end{array}$ & $\begin{array}{c}\text { Wear rate } \\
\left(\mathbf{1 0 ^ { - 6 }} \mathbf{~ m m / N m}\right)\end{array}$ & $\begin{array}{c}\text { Wear track } \\
\mathbf{R q}(\mathbf{n m})\end{array}$ \\
\hline Atm. air at $30^{\circ} \mathrm{C}$ & $0.52 \pm 0.07$ & $0.47 \pm 0.07$ & $1.7 \pm 0.3$ & $66 \pm 15$ \\
\hline Atm. air at $80^{\circ} \mathrm{C}$ & $0.49 \pm 0.02$ & $0.34 \pm 0.01$ & $3.8 \pm 0.2$ & $87 \pm 39$ \\
\hline $\mathrm{R} 134 \mathrm{a}^{*}$ at $30^{\circ} \mathrm{C}$ & $0.44 \pm 0.02$ & $0.39 \pm 0.02$ & $1.8 \pm 0.7$ & $54 \pm 29$ \\
\hline $\mathrm{R} 134 \mathrm{a}^{*}$ at $80^{\circ} \mathrm{C}$ & $0.43 \pm 0.02$ & $0.37 \pm 0.01$ & $3.2 \pm 0.7$ & $65 \pm 55$ \\
\hline none & - & - & - & $7 \pm 3$ \\
\hline${ }^{*}$ R134a is the commercial name for tetrafluorethane refrigerant fluid.
\end{tabular}

Graphite based tribo-layers were observed on counter bodies surface after sliding tests. Higher test temperatures enhanced the tribo-layers formation and the presence of atmospheric air resulted in graphite structure with higher disorder.

\section{Acknowledgments}

The authors wish to thank CNPq and Capes/Proex for financial support.

\section{REFERENCES}

1 Lorentzen $\mathrm{G}$. The use of natural refrigerants - a complete solution to the CFC/HCFC predicament. International Journal of Refrigeration. 1995, 18(3): 190-197.

2 Sheiretov T, Vanglabbeek W, Cusano C. Evaluation of the tribological properties of polyimide and poly(amide-imide) polymers in a refrigerant environment. Tribology Transactions. 1995, 38(4): 914-922.

3 Cannaday ML, Polycarpou AA. Tribology of unfilled and filled polymeric surfaces in refrigerant environment for compressor applications. Tribology Letters. 2005, 19(4): 249-262.

4 Demas NG, Polycarpou AA. Tribological performance of PTFE-based coatings for airconditioning compressors. Surface \& Coatings Technology. 2008, 203(3-4): 307-316.

5 Dascalescu D, Polychronopoulou K, Polycarpou AA. The significance of tribochemistry on the performance of PTFE-based coatings in $\mathrm{CO} 2$ refrigerant environment. Surface \& Coatings Technology. 2009, 204 (3): 319-329.

6 Nunez EE, Yeo SM, Polychronopoulou K, Polycarpou AA. Tribological study of high bearing blended polymer-based coatings for air-conditioning and refrigeration compressors. Surface \& Coatings Technology. 2011, 205 (8-9): 2994-3005.

7 Yeo SM, Polycarpou AA. Tribological performance of PTFE- and PEEK-based coatings under oil-less compressor conditions. Wear. 2012, 296 (1-2) 638-647.

8 Solzak TA, Polycarpou AA. Tribology of WC/C coatings for use in oil-less piston-type compressors. Surface \& Coating Technology. 2006, 201(7): 4260-4265.

9 De Mello DB, Binder R, Demas NG, Polycarpou AA. Effect of the actual environment present in hermetic compressors on the tribological behaviour of a Si-rich multifunctional DLC coating. Wear. 2009, 267(5-8) 907-915.

10 Oil-less linear compressor launched. Cooling Spot. Trans [internet]; 2004 [cited 2014 mar 20]. Available from: http://www.coolingpost.com/world-news/oil-less-linearcompressor-launched/.

11 Schroeder R, Torres FW, Binder C, Klein AN, De Mello DB. Failure mode in sliding wear of PEEK based composites. Wear. 2013, 301(1-2): 717-726.

12 McCook NL, Hamilton MA, Burris DL, Sawyer WG. Tribological results of PEEK nanocomposites in dry sliding against $440 \mathrm{C}$ in various gas environments. Wear. 2007, 262(11-12): 1511-1515.

13 Stachowiak GW, Batchelor AW. Engineering Tribology. 3nd ed. Oxford: ButterworthHeinemann; 2005.

\footnotetext{
* Technical contribution to the $2^{\text {nd }}$ International Brazilian Conference on Tribology - TriboBR 2014, November $3^{\text {rd }}$ to $5^{\text {th }}$, 2014, Foz do Iguaçu, PR, Brazil.
} 
